DOI: https://doi.org/10.47405/mjssh.v6i11.1172

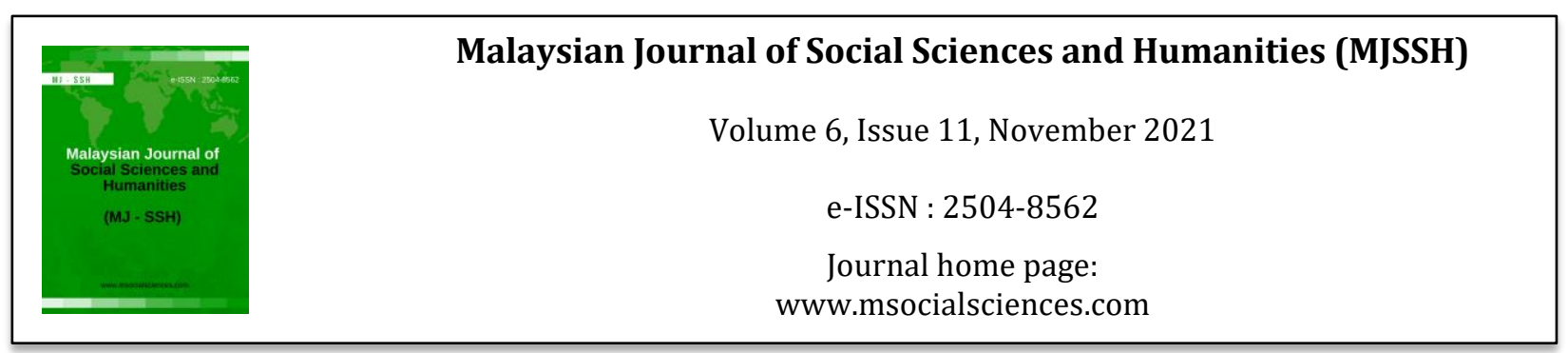

\title{
Systematic Review of Stress and Coping Strategies during Pandemic COVID- 19 Among Students in Higher Learning Institutions
}

\author{
Abdul Rashid Abdul Aziz' ${ }^{1}$, Nor Hamizah Ab Razak' ${ }^{1}$, Nathratul Ayeshah Zulkifli², \\ Mohamad Isa Amat', Mohd Zaini Othman ${ }^{3}$, Nurun Najihah Musa ${ }^{1}$ \\ 1Faculty of Leadership \& Management, Universiti Sains Islam Malaysia (USIM), Malaysia \\ ${ }^{2}$ Faculty of Health Sciences, Universiti Sains Islam Malaysia (USIM), Malaysia \\ ${ }^{3}$ Strategic Communication Center, Universiti Sains Islam Malaysia (USIM), Malaysia
}

Correspondence: Abdul Rashid Abdul Aziz (rashid@usim.edu.my)

\begin{abstract}
The Coronavirus Disease 2019 (COVID-19) pandemic that strike Malaysia and the rest of the world has given a huge variety of implications especially in the aspect of mental health. Students are no exception in dealing with it. It requires every student to adapt to the new norms that exist in teaching and learning (T\&L) system. Thus, this study aims to examine the coping strategies and stress management that can be applied by students in dealing with stress during the pandemic. To achieve this goal a systematic search was conducted, and a simple thematic analysis approach was used to identify the coping strategies among students at higher learning institutions as discussed by previous researchers on similar topics from three search engines on (1) Scopus, (2) Social Science Citation Index (SSCI), and (3) Science Direct from 2015 to 2021 to determine the latest evidence and observations. A literature review of 10 relevant studies was rigorously analysed to get understanding of coping strategies and stress management amongst students at higher learning institutions. The findings show that there are four critical factors in stress management including (1) time management, (2) internet access issues, (2) academic workload and (4) adaptation to new norms. In addition, there are three types of coping strategies that students can do in coping with stress. Research pertaining to these issues are still lacking. This study is seen to be a new platform and guidelines especially for educational institutions to ensure that every student is equipped with stress management skills that can lead to personal well -being.
\end{abstract}

Keywords: coping strategies, stress management, stress, mental health, personal well-being

\section{Introduction}

Corona virus or better known as COVID-19 caused the outbreak of pandemics that experienced around the world and had a major impact on all levels of society (Zhou, 2020) including students at both public and private higher learning institutions. First detected around November 2019, the COVID-19 outbreak has begun in Wuhan, China. The viruses are spreading to other countries rapidly. As a result, this pandemic has a significant impact in terms of economics, social interaction, administration of government and private agencies, including educational institutions, which also received the impact of the pandemic. Looking at the increasing trend of infection, at the end of January 2020, the spread of COVID-19 was declared by the WHO as a public health emergency that needs to be given concern globally. As of early October 2021, WHO statistics revealed that there has been a total of 233 million 
cases of infection and 4.7 million deaths worldwide reported since the beginning of the emergence of this pandemic (WHO, 2021).

In Malaysia, statistics until early October 2021 showed that there were 2.27 million cases of infection, and 26 thousand deaths were recorded (Ministry of Health Malaysia, 2021). The government has taken drastic measures by implementing the Movement Control Order (MCO) in phases according to the level of transmission to curb the spread of COVID-19 in the country. When the third wave of COVID19 outbreak occurred, the government re-enforced MCO by fully implementing MCO 3.0 with the expectation that this transmission is gradually recover according to certain phases in each corner of the country (Salleh et al., 2021). As a result, during October and November 2021, infection trends nationwide showed a decline and serious cases at stage 3 and 4 that requiring intensive and respiratory assistance were also declining (Ministry of Health Malaysia, 2021). In general, the COVID-19 outbreak has significantly affected well-being at the individual and community levels (Puwaneswary, 2020) as well as at the same time it causes psychological stress (Pfefferbaum, 2020).

\section{Stress and Coping Strategies}

Online learning is inevitable these days. In fact, online teaching and learning through digital platforms has evolved progressively over the past few decades in the world of education has become and issues being discussed widely from various parties. However, when the MCO was enforced by the government on March $18^{\text {th }}, 2020$ to curb and control the spread of COVID-19 in the country, it affected various sectors and activities including educational institutions from primary schools to higher learning institutions had to be closed. As a result, all teaching and learning (T\&L) activities involving students face to face were not allowed and the implementation of T\&L shifted to a new norm of being conducted online. These students have lost their motivation and pace for their study. As they learned from home, a lot of library research needs is critical and internet connection disturbance affected the quality of teaching delivery. Nevertheless, these abrupt changes certainly require a process of adaptation and invite stress because of the anxiety experienced among students. Thus, most university students experienced culture shock due to this drastic change as the online T\&L method was a platform that had not been fully explored in universities before COVID-19 hit.

The enforcement of MCO by the government is a necessary step that had to be taken to curb the spread of COVID-19 among Malaysians became uncontrollable and increasingly serious. However, the implementation of PKP has formed a group of people who experience psychological stress such as fear, anxiety, stress , worry and depression. This is due to social activities that used to be one of the ways of life of Malaysians can no longer be carried out. In a meta-analysis study conducted by Julianne HoltLunstad et. al (2015) concluded that the risk of death increased to 29 percent for individuals experiencing chronic social isolation.

The implementation of online T\&L prolonged until 2021 as the MCO is continued by the government in certain phases as the spread of the COVID-19 pandemic is remain a major concern. The impact of the COVID-19 pandemic in influencing stress on students can be seen in two situations; group of students who facing the COVID-19 infections and students undergoing MCO that gazetted by the government. Students facing the pandemic are classified as students infected with the pandemic or in contact with patients and family members, frontliners consisting of medical officers, health workers, and enforcement (police and military). Meanwhile, students undergoing MCO are referred to as a group that faces difficulties in adapting to the new norms of online T\&L.

The stress experienced by students makes it difficult for them to learn online effectively even though the online T\&L method is the only medium to ensure continuity to the teaching and learning process continues to occur as the COVID-19 pandemic hits the country. Therefore, the objective of this study was to look at the stress and coping strategies of students in facing learning challenges during the COVID-19 pandemic. 


\section{Literature Review}

\section{COVID-19 and New Norms}

The COVID-19 pandemic has affected various sectors, especially health, economy, public awareness, as well as the limitations of social interaction which ultimately leads to stress and bad consequences if not handled properly. Previous studies reported significant effects of the COVID-19 pandemic experienced worldwide (Pan, 2020). This pandemic also has a significant impact on the education system, particularly the impact due to the closure of string higher education institutions from the enforcement of the introduced MCO (Simon, 2020).

Higher education institutions were also found to be affected due to the spread of this pandemic where the implementation of the system needs to be changed and adapted according to the new norms (Azlan, 2020). Online learning is a teaching and learning session conducted through a digital platform is seen to be increasingly popular and accepted in the world of education and it is often a discussion about its positive and negative effects by various parties (Wong, 2013). Teaching and learning sessions should be applied online instead of face to face and in groups as practiced so far following the enforcement of MCO from March 2020. Therefore, all related teaching and learning activities involving students faceto-face are prohibited and replaced online. The implementation of such methods will continue, as MCO is still ongoing to this day and is not yet seen to be coming to an end (Kundu, 2020).

Among the e-learning platforms used today are Webex, Google Meet, Google Classroom, Zoom, Telegram, Whatsapp and Youtube. With the use of these platforms, although face-to-face T\&L sessions cannot be implemented during the COVID-19 pandemic, however, the interaction of instructors and students can be continued despite there are limitations and constraints expected to occur. In addition, with these online platforms, it can be a medium of assistance for students to acquire knowledge in a more organized and structured so as to be able to complete the academic syllabus that has been planned. However, these implementation reformations also have a negative impact on all students, particularly university students. One of them is the effects of stress which are closely related to emotional status, optimal body health as well as high adaptive adjustment needs among them (Kamsani, 2021).

Most university students also experienced significant impact especially learning culture shock due to adaptive changes due to this pandemic. The shift from conventional teaching methods to e-learning requires a high process of adaptation among students also invites the stress of their anxiety strings. One of the studies that has been conducted found that the negative impact of e-learning where there are students who experience decreased motivation to learn, difficulty to focus on lessons, as well as other technical problems such as instability of internet access during online learning sessions (Azlan, 2020).

There are several preliminary studies that have been conducted to look at the readiness and challenges experienced by students when faced with online learning sessions. Undeniably, students are among the most affected because they have to switch from conventional learning practices that is face to face to online to ensure the existing learning process is not disrupted, especially when the country has to face the impact of the COVID-19 pandemic (Chung, Mohamed Noor \& Mathew 2020). In fact, this change is not only happening in Malaysia but also involving other countries such as the United Kingdom. For example, the University of Cambridge also implemented online learning sessions for the 2020/2021 academic session to curb the spread of the pandemic on students and these changes to some extent impacted the existing learning process (Europe News, 2020).

The main challenge in the aspect of online learning is the weakness of time management among students. Past studies (Misra \& McKean, 2000; Kearns \& Gardiner, 2007) have shown that time management has a relationship with stress levels among students. Thus, poor time management will increase students' stress levels because they have to divide their time between lecture schedules, tutorials and assignments. In fact, the lack of infrastructure at home is also a constraint for self learning (Kassim, 2010). Face -to -face learning can make a student more focused than online learning. This is due to during online learning, students who are at home are freely to do anything without the 
direct monitoring of the instructor. In addition, "distraction" of the home environment can also cause students to not focus on the T\&L process and other commitments found at home such as helping parents and daily responsibilities have caused students 'time management to become disorganized (Abdul Rashid et al., 2020).

\section{Coping Strategy}

The transactional model of stress and coping developed by Lazarus and Folkman (1984) were used in this study to aid understanding of the concept of academic stress and its interaction with online learning challenges. In describing stress as a dynamic process, Lazarus has developed a conceptual framework named Lazarus and Folkman's Transactional Theory of Stress and Coping, TTSC (Lazarus, 1966; Lazarus, 1984). This theory is very relevant in discussing coping strategies for students in facing the challenges of online learning.

In this aspect of coping strategies, Lazarus and Folkman have classified coping strategies into two aspects: first is problem -focused strategies, where problem -focused strategies are defined as strategies involving behaviors that include strategies such as seeking help and taking direct action on situations and challenges. According to Lazarus (1986), this strategy includes how to face problems (confrontative coping), how to seek social support (seeking social support) and plan ways to solve problems (plan -full problem solving). This strategy is then further developed into an active way of coping, planning, suppression of competing activities and seeking social support for emotional reasons (Carver, 1989). Thus, this problem -focused strategy is seen to be effective in managing the academic stress faced by students through online learning (Nurma, 2019).

The second strategy of Lazarus is an emotional focused strategy. Emotion -focused strategies are cognitive processes that consist of positive thinking and emotional expression. The purpose is to develop a strategy on how to adapt to the stress of a situation by reducing the stress experienced. This strategy is manifestation of self-control, seeking social support, distancing, positive appraisal, accepting responsibilities and escape/escape. avoidance) (Lazarus, 1986).

According to Carver (1989), this strategy can be done with several steps, namely seeking social support for emotional problems (seeking social support for emotional reasons), acceptance of the source of stress (acceptance), how to turn to religious teachings (acceptance, turning to religion), as well as the action force strategy of the humor method. This emotion -focused strategy can be used when the individual is unable to change the prevailing environmental conditions. It is a method that involves selective attention in which the individual deliberately focuses on certain aspects that are relevant or unrelated to his problem, positive comparisons and behaviors to avoid or reduce stress (Lazarus, 1984).

\section{Methodology}

This study was a qualitative study that employed a systematic literature review method. This method applies a systematic search to identify aspects of stress management and coping strategies among students. According to Higgins et al. (2011) systematic literature review is a study that aims to find and analyze in a comprehensive, structured, no doubt and can be repeated in the next process. Through a systematic study, the researchers can show that the study to be done is well -founded and identify gaps and directions that need to be addressed in future studies. In addition, the researchers also conducted four phases of research including (1) identification, (2) screening, eligibility, and inclusion (Xiao \& Watson, 2019).

The focus of this study was to understand the factors contributing to stress and the coping strategies used by most students during the COVID-19 pandemic. Therefore, a total of three search engines $(n=3)$ in the database are used to find articles and journals including (1) Scopus, (2) Social Sciences Citation Index (SSCI) and (3) Science Direct. All three of these search engines were used as these search engines have a lot of high indexed articles. Data search was used by focusing on several Malay as well as English terms such as 'stress', 'coping strategy', 'stress' and 'action force'. However, researchers 
also paid attention to other emerging phrases such as mental health, well-being, fear, anxiety, suicide and problematic behavior. The meaning behind each concept is analyzed to better understand the issues discussed.

In addition, inclusion and exclusion criteria were also included to ensure that the selected articles were timely, good quality and appropriate for the study's purpose. Article selection criteria include articles published between 2015 to 2021 only and the type of article selected was a review article and original research article. In addition, the selected articles also only involve open access articles that are intended to facilitate the article acquisition and download process. Next, the field of study of the selected article is the field of social sciences covering all countries. For language selection, only both Malay and English written articles were selected. In addition, only article with complete references were selected into this study. While for exclusion criteria; those articles published from the proceedings, thesis or dissertation and magazines were not included in the selection of articles for this study.

Findings from the database showed a total of 180 articles were found related to the keywords. Next, after the screening process (screening) of the abstract was carried out a total of 125 articles were found. As a result of the screening of full articles, it was found that 40 articles met the specified characteristics. All 40 articles then went through an eligibility process with an abstract reading process as well as full articles and then analyzed and categorized according to the scope of the study to gain a better understanding, on stress issues and coping strategies among students. Out of 40 articles, only ten articles met the scope of the study. 30 articles were removed in view of unclear methodology and incomplete references.

\section{Result \& Discussion}

Ten literature reviews have been identified as important indicators to see the challenges of stress faced by students and the form of coping strategies to achieve solutions that have been implemented. The findings depicted in Table 1 as below;

Table 1: Review of Articles

\begin{tabular}{|c|c|c|c|}
\hline No. & Author \& Year & Study background & Findings \\
\hline 1 & $\begin{array}{l}\text { Saad, Wan Zaimah, } \\
\text { Zahrul Akmal, } \\
\text { Harliana, Hussain \& } \\
\text { Khairul Azman } \\
\text { (2018) }\end{array}$ & $\begin{array}{l}\text { Stress management } \\
\text { among university } \\
\text { students }\end{array}$ & $\begin{array}{l}\text { There are three stress factors have been } \\
\text { identified; (1) the most important is the } \\
\text { academic factor, followed by (2) the time } \\
\text { management factor and then (3) the social } \\
\text { relationship factor. The study found that the } \\
\text { action of managing stress has been divided } \\
\text { into three, namely time management, social } \\
\text { relationships and seeking advice and } \\
\text { guidance from counseling. All three of these } \\
\text { stress management actions show a moderate } \\
\text { level of interpretation indicating that the } \\
\text { ways of managing stress stated in the survey } \\
\text { form are among the most frequently used } \\
\text { ways to cope with stress. }\end{array}$ \\
\hline
\end{tabular}

2 Norhana, A., Fahmi, A., Aslinda, M. \& Zazalli, L. (2020).
Analysis of stress factors influencing community college students
The results of the study found that, in terms of time management, students felt quite stressed to organize their time between the workload of learning assignments and homework as they had to study online. Students adapt and create self -control during new norms for the sake of a career future. 
3 Che Ahmad Azlan, Jeannie Hsiu Ding Wong, Li Kuo Tan, Muhammad Shahrun Nizam, A.D.Huri, Ngie Min Ung, Vinod Pallath, Christina Phoay Lay Tan, Chai Hong Yeong \& Kwan Hoong Ng. (2020).

4 Abdul Rashid, A, A., Amin Al, H, S., Umi Hamidaton, M, S, L. $\&$ Raja Nur Syafiqah, R, A. (2020).

5 AlAteeq, D, A., Aljhani, S. \& AlEesa, D. (2020). Masfety, V, K. \& Swendsen, J, D. (2020).

7 Yasmin, H., Khalil, S., \& Mazhar, R. (2020).
Teaching and learning of postgraduate students using online methods during the COVID-19 pandemic: A Case Study in Malaysia.

Strategies for the development of aspects of self-wellbeing to cope with academic stress during the COVID-19 pandemic

The pressure of the new norm among students during online classes

Stress and anxiety of students in France during the COVID-19 pandemic

Stress management among students and its impact on learning effectiveness
The results of the study found that students reported a decrease in morale, loss of motivation, difficulty in focusing on their lessons and internet connection problems throughout the online learning sessions. In addition, this new learning norm requires students to be more independent and always ready to face challenges in organizing their own affairs and learning.

The study found that among the challenges that need to be faced by students when undergoing online learning are self adjustment, internet access problems, self learning and financial issues. Students face these problems without the help of peers as well as lecturers and an environment conducive to learning causes student stress to intensify. The results of the study also suggest several solution measures to this problem such as forming aspects of self well -being to cope with stress during the pandemic season, improving aspects of emotional, spiritual, mental and physical well -being.

The study found an increase in student stress levels when the COVID-19 outbreak struck especially for students taking difficult courses or programs such as medicine and dentistry. Online stress management needs to be implemented to overcome this problem.

The study found that there was an increase in the level of stress from moderate to severe during the control period. Furthermore, the phase of transition from high school to the university realm also contributes to the increased level of stress among university students. They have to adjust to the transition phase without meeting face to face with friends, in fact some do not have the opportunity to get to know their friends directly due to the closure of the education sector.

Findings of the study show that among the reasons students become stressed are too much workload, exam grades, future, health, family problems, financial problems and personal problems. As a student, academic problems become a major problem plaguing students. Among the measures proposed to help students reduce stress is by building a 
Zainora,

Noorhafizah,

Norazman \& Anuar (2021)

9

Nor Sahara, M \&

Zulkarnain, A, M. (2021)
10 Woon, L. S.-C., Abdullah, M. F., Sidi, H., Mansor, N. S., \& Jaafar, N. R. (2021).
Comparison among students of higher learning institutions on stress symptoms experienced during online teaching and learning sessions of the COVID-19 era

Student readiness to follow online learning during movement control order (MCO) to curb COVID-19 student -friendly environment, the body is responsible for helping the welfare of students and families reduce stress by not placing too high expectations on students. In conclusion, students need to be exposed to the right way to manage stress in life as a student.

There are four symptoms of stress namely physical, psychological, physical and behavioral disorders. The results of the study found that for USIM respondents the level for all three symptoms was moderate but for behavioral symptoms showed a high level. While for KUIS respondents, the level shown is moderate for all four types of symptoms. The result was found to overcome stress by practicing the teachings of Islam comprehensively in daily life

The study found that family income and students' level of readiness have a significant relationship that students will be better prepared to face online learning if family income increases. This is because when there is an increase in family income, their parents can provide facilities and amenities for them to undergo online learning. Furthermore, they do not have to worry about their family's financial problems and can concentrate fully on learning. Ultimately, the relevant parties must help students to undergo online learning by providing them with complete facilities.

Depression, anxiety and the COVID-19 pandemic: Symptoms among university students after MCO ended
The results of the study found that student stress due to learning difficulties during the COVID-19 pandemic raised concerns about the future due to possible delays in graduation, lack of practical learning, difficulty in attending online classes due to internet problems, difficulty adapting to new learning styles, and lost momentum to learn. However, there are other sources of stress faced by university students. Among them, not being able to perform daily routines throughout COVID-19, experiencing fear when having physical symptoms such as fever, flu, and cough led to the thought that they were infected with COVID-19. While a small proportion of subjects had other stresscausing issues such as marital problems, family concerns, and had a history of being quarantined for being infected with COVID19. 


\section{Contributing Factors Towards Stress}

Based on the above analysis, the findings explain there are four factors that contribute to stress during the COVID-19 pandemic: (1) time management, (2) internet access issues, (3) academic workload and (4) adaptation to new norms.

In efforts to prevent the spread of the COVID-19 pandemic as well as reduce the burden on hospitals, almost the entire country has taken social distancing measures proactively (Sood, 2020). All communities around the world were instructed to remain at home as well as the education system was closed, and classes were shifted to the distance learning model from home (Golberstein et al. 2020). Previously, students attended classes face-to-face and could pay full attention to lessons, however the current situation is different when classes are only held online at home which demands such a neat division of time. This is crucial as a student lives at home with the family, the student not only plays the role of a student but also bears the responsibility as a child. In addition, there are also students who have to divide their study time with work to help parents whose income is affected by the pandemic. Based on the study of Sharer et al. (2021), the issue of lack of time among students mostly arises from students with low socioeconomic status. However, the study of Sheela et al. (2020) found that students who did not live with families showed higher levels of stress than students who lived with families during a pandemic.

In Malaysia, the use of the internet is a major requirement in carrying out daily tasks by everyone. The results of a survey questionnaire found that the results of respondents reached $91.3 \%$ agreed that the internet is a key requirement in increasing their daily productivity (Md Luqmanul, 2021). Along with the development and advancement of information and communication technology, the use of the internet in Malaysia is also increasing throughout the year (Talha, 2020). However, this increase is not in line with access to the internet as not all homes have a good broadband network coverage to help them access the internet.

The enforcement of MCO indirectly creating new norms in matters involving day-to-day communication such as employment matters for example has begun to shift from a face-to-face approach to an online medium. In the aspect of communication such as giving instructions, discussions, etc. should be done online to minimize face-to-face meetings between the two parties (Jamaluddin, 2020). This technology -based approach presents a challenge to each individual in getting used to using online technology tools as it is something new while overcoming the difficulties in accessing the internet. Challenges increase when there is an increase in workload to meet the needs of work and personal matters involving the psychology, emotions or social of the human being himself (Azman, 2020).

The same thing happens in the implementation of $T \& L$ because to ensure the quality of $T \& L$ runs better, internet access must be in a satisfactory condition on behalf of instructors and students. If internet access coverage is inadequate or problematic, it will be feared to interfere with the effectiveness of online T\&L (Yahaya, 2021). For example, the problem will be more pronounced for students who have to take online classes from their respective homes or villages who face internet access constraints. There is a significant difference between internet access for students living in urban compared to rural areas with most students who obtain better internet access are students living in urban areas. Meanwhile, for some students who live in rural areas they will have trouble getting good internet access.

In addition, some students also face financial challenges that disturb their emotions because many students feel burdened when they have to spend money to buy internet data. Online T\&L requires students to fully attend classes, exams as well as submit assignments online. As a result, students need faster internet line access without any unwanted interruptions that have to be paid with high price (Yahaya, 2020).

The transformation in learning methods to online medium also involves other countries such as the United Kingdom. For example, the University of Cambridge also implemented an online learning 
session for the 2020/2021 academic session to curb the spread of COVID-19 on students and this change to some extent has an impact on the existing learning process and this proves it is not only happening in Malaysia but also occurs abroad to prevent the spread of pandemics (Europe News, 2020). In addition, according to Tam (2020), it is estimated that more than 421 million students were affected by the COVID-19 pandemic when their learning process for the current study session was disrupted due to educational institutions having to close immediately to ensure the safety of staff and students at risk of infection. In addition, there are several challenges faced by students in undergoing online learning involving the ability to adapt to technological changes as it involves digital learning as well as changes in attitudes to accept online learning practices implemented (Ismail, 2020).

Based on the current scenario, it can be observed that through the online teaching and learning method (e-learning) students are seen to have more potential to face academic problems that are more often referred to as academic stress. Academic stress is defined as an unpleasant state of a string of demands that need to be met by a student thus triggering anxiety and affecting well -being in his / her studies (Johari, 2019). The academic stress experienced by students mostly comes from various demands at the university with four categories of academic stress that often occur among students including interpersonal demand, physical demand, role demand and task demand (Desmita, 2010).

Being a university student is a challenge where the individual need to understand and adapts to something foreign to them such as changes and differences in lifestyle, different university learning system than in school, level of difficulty of learning content and environment at the university level that requires a high level of maturity among the students of the study. In academic assessment, they need to achieve the minimum value set by the university as a condition to graduate later (Johar, 2020). There are several other preliminary studies that have been conducted to look at the readiness and challenges experienced by students when faced with online learning sessions. Undoubtedly, students are among the most affected (Chung, 2020) because they have to move from conventional learning practices that is face to face to online (Nawii, 2020) to ensure the existing learning process is not disrupted, especially when the country has to face the impact. outbreak COVID-19 (Rosdi, 2021).

Therefore, it can be assumed that if students fail to use appropriate strategies in meeting all the demands and changes in this pandemic, then the stress they face will worsen and result in the impairment of all aspects of their well -being, thus causing a serious impact on psychological health (Aihie, 2019). Their academic performance will also decline and the most feared is that they will be at risk of losing self -confidence (Friedlander, 2007).

According to Elias (2011), the results of his study found that stress and academic performance of students are closely related to each other. Students are at risk for mental health disorders such as depression, anxiety symptoms or nervousness (Nwachukwu, 2020) as well as drug abuse as a result of self -treatment attempts that eventually lead them to get stuck with negative behavior problems (Bennett, 2014). In another study on academic stress, coping and social adaptation among 424 respondents found that academic stress, coping and social adaptation had a significant influence on students 'psychological well-being (Selian, 2020).

Stress is also experienced by students when this group has to adapt to new norms in their life routines. The implementation of MCO has changed the pattern of life of the community, including students. Student life is synonymous with waking up in the morning to go to college, socializing with friends, discussing, reviewing lessons with friends and so on. However, the existence of COVID-19 and MCO forced students to change the daily routine of students who are no longer concentrated on campus instead these groups had to remain at home with most of the time spent with activities on smartphone screens and devices. These changes in the routine of life indirectly put stress and threaten the self -well -being of the students because they have to go through it for a long period of time.

The challenge of learning new norms requires a high level of resilience among students (Gao, 2020). Through this e-learning, the attitude of independence and resilience in the face of what kind of challenges should be in them (Johar, 2020). They need to be more independent and always wise in arranging time for learning as well as a high level of control over their emotions and physical in these 
challenging times (Jafar, 2020). Other factors that also influence the preparation of students are skills in the use of computers, attitude to learn the latest resources as well as computer facilities and gadgets required (Tasir, 2006). A study from Browning (2021) found that most students adopt poor quality sleep patterns during MCO and this unhealthy lifestyle can also contribute to stress and strain on the students concerned and it coincides with the study of Almojali et al. (2017) who found that there was a significant relationship between stress and poor sleep quality. Similarly, Pascoe et al. (2020) also stated that stress -related disorders on sleep quality and quantity are important factors contributing to learning disabilities and well -being.

The challenge of learning new norms requires a high level of resilience among students (Gao, 2020). Through this e-learning, the attitude of independence and resilience in the face of what kind of challenges should be in them (Johar, 2020). They need to be more independent and always wise in arranging time for learning as well as a high level of control over their emotions and physical in these challenging times (Jafar, 2020). Other factors that also influence the preparation of students are skills in the use of computers, attitude to learn the latest resources as well as computer facilities and gadgets required (Tasir, 2006). A study from Browning (2021) found that most students adopt poor quality sleep patterns during MCO and this unhealthy lifestyle can also contribute to stress and strain on the students concerned and it coincides with the study of Almojali et al. (2017) who found that there was a significant relationship between stress and poor sleep quality. Similarly, Pascoe et al. (2020) also stated that stress -related disorders on sleep quality and quantity are important factors contributing to learning disabilities and well -being.

\section{Student's Coping Strategies in Dealing with Stress}

The analysis conducted has shown that the coping strategies used by students can be divided into three strategies: (1) problem focused strategy, (2) emotion focused strategy and (3) avoidant coping strategy. The coping strategies used by students are various and according to a study by Ferliss (2009) found that university students more often use emotional -based coping strategies such as relaxation and spiritual support, as well as problem -based coping by focusing on problem solving as well as gaining social support and sharing problems with close friends. In addition, there are some students who do the method of forgetting or avoiding all the distractions that are the cause of student stress.

According to the findings of a resilience study on Universiti Malaysia Sabah (UMS) students, almost $82 \%$ of students practice strategies through emotion-based methods with students tending to practice relaxation such as listening to music, reading books, playing musical instruments and watching television. From the findings of the same study, a total of $73.9 \%$ of students always try to solve the things that are the cause of the problems experienced and a few students try to solve problems well according to their ability. Apart from that, coping strategies in the form of spiritual support are also often used by students with a total of $77.5 \%$ of students often praying for God to protect them and ask for help and guidance so that the problems faced will be resolved.

As for avoidance coping, Linn (1980) found that students tend to forget their stress disorders by often having conversations with friends who act as intermediaries between their life problems. This resilience requires precise self -control, positive self -assessment and frequent social support as evidenced in the findings of a study conducted by Sinha et al. (2020) to first year undergraduate university students in India and Canada. Through the study, a total of 58\% of students have obtained support from others especially from parents and friends in dealing with stress and life problems experienced.

\section{Conclusion}

Overall, through this study it proves that students in institutions of higher learning are among the community groups affected by the spread of COVID-19 and the implementation of MCO by the government to curb this pandemic. The COVID-19 pandemic is a new pandemic that has had a huge impact around the world as it has directly affected drastic changes to the routine of human life 
including the education system especially the transition of face-to-face T\&L medium to online platforms that create pressure on university students. Therefore, by clearly identifying the challenges faced by students during this online T\&L and the action strategies applied by them, it will be a comprehensive and accurate reference to policy makers especially in preparing appropriate strategic proposals and plans in the new norm education.

The Ministry of Higher Education, University Management, faculty administration and other parties that have a direct relationship in the formulation and implementation of policies related to the management of academic affairs in universities will have a stronger, more concise and inclusive foundation in making judgments when they base the findings of this study because in the end it is to ensure that the welfare and mental health aspects of students are always taken care of. At the same time, institutions of higher learning will have a greater role to play in ensuring that every student is equipped with stress management skills that can lead to personal well -being in turn helping them maintain excellence in academic achievement.

\section{Acknowledgement}

An appreciation is extended to Universiti Sains Islam Malaysia for funding the USIM Special Research Grant (Current Issues) 2021 entitled "Significance of Stress Management Facing the Challenges of COVID-19: An Overview of USIM Students' Coping Strategies Towards Personal Well-Being" (PPPI/KHAS_FKP/USIM /17521).

\section{References}

Abdul Rashid Abdul Aziz, Amin Al Haadi Shafie, Umi Hamidaton Mohd Soffian Lee, Raja Nur Syafiqah Raja Ashaari. (2020). Strategi Pembangunan Aspek Kesejahteraan Kendiri bagi Mendepani Tekanan Akademik Semasa Wabak COVID-19. Malaysian Journal of Social Sciences and Humanities (MJSSH), 5(12), 16-30.

Abdul Rashid Abdul Aziz. (2020). Wabak Covid-19: Penyesuaian Kendiri terhadap Norma Baharu. Artikel diterbitkan dalam ruangan In our words (Fi ra'yinaa) USIM secara digital. Capaian pada 13 Februari 2020 dari https://www.usim.edu.my/ms/berita/in-our-words-ms/wabak-covid-19penyesuaian-kendiri-terhadap-norma-baharu/

Abdul Rashid, A, A., Amin Al, H, S., Umi Hamidaton, M, S, L. \& Raja Nur Syafiqah, R, A. (2020). Strategi Pembangunan Aspek Kesejahteraan Kendiri bagi Mendepani Tekanan Akademik Semasa Wabak COVID-19. Malaysian Journal of Social Sciences and Humanities (MJSSH), 5(12), 16-30. Retrieved from https://msocialsciences.com/index.php/mjssh/article/view/594/413.

Abdul Rashid, A, A., Nurhafizah, M, S. \& Nor Hamizah A, R. (2020). Wabak Covid-19: Pengurusan Aspek Kesihatan Mental Semasa Norma Baharu. International Journal of Social Science Research, 2(4), 156-174.

Ahmad, A. R., Murad, H. R. (2020) The impact of social media on panic during the COVID-19 pandemic in iraqi kurdistan: Online questionnaire study. J Med Internet Res.; 22(5), e19556. doi: $10.2196 / 19556$

Aihie, O. N., \& Ohanaka, B. I. (2019). Perceived academic stress among undergraduate students in a Nigerian University. Journal of Educational and Social Research, 9(2), 56-56.

AlAteeq, D, A., Aljhani, S. \& AlEesa, D. (2020). Perceived Stress Among Students in Virtual Classrooms During The COVID-19 Outbreak In KSA. Journal of Taibah University Medical Sciences, $\quad$ Volume 15(5). Retrieved from https://www.sciencedirect.com/science/article/pii/S1658361220301128

Almojali, A. I., Almalki, S. A., Alothman, A. S., Masuadi, E. M., \& Alaqeel, M. K. (2017). The prevalence and association of stress with sleep quality among medical students. Journal of Epidemiology and Global Health, 7(3), 169-174. 
Aziz, A. R. A., Zulkifli, N. A., Kasmani, M. F., \& Khan, A. (2021). Exploring Psychological Stress among Health Care Worker AMID Pandemic COVID-19 in Malaysia. Revista Geintec-Gestao Inovacao E Tecnologias, 11(4), 2127-2145.

Azlan, C. A., Wong, J. H. D., Tan, L. K., Huri, M. S. N. A., Ung, N. M., Pallath, V., ... \& Ng, K. H. (2020). Teaching and learning of postgraduate medical physics using Internet-based e-learning during the COVID-19 pandemic-A case study from Malaysia. Physica Medica, 80, 10-16

Azman. A., Jamir Singh, P. S., Parker, J. \& Crabtree, S. A. (2020). Addressing competency requirements of social work students during the COVID-19 pandemic in Malaysia. Social Work Education, 39(8),1058-1065, DOI:10.1080/02615479.2020.1815692

Bennett, T. H., \& Holloway, K. R. (2014). Drug misuse among university students in the UK: implications for prevention. Substance use \& misuse, 49(4), 448-455.

Carver, C. S., Scheier, M. F., \& Weintraub, J. K. (1989). Assessing coping strategies: a theoretically based approach. Journal of personality and social psychology, 56(2), 267

Chung, E., Noor, N. M., \& Mathew, V. N. (2020). Are you ready? An assessment of online learning readiness among university students. International Journal of Academic Research in Progressive Education and Development, 9(1), 301-317.

Chung, E., Noor, N. M., \& Vloreen Nity Mathew. 2020. Are You Ready? An Assessment of Online Learning Readiness among University Students. International Journal of Academic Research in Progressive Education and Development, 9(1), 301-317.

Daud, Zainora, Noorhafizah Mohd Haridi, Norazman Alias, and Anuar Hasin. "Kajian Perbandingan Kalangan Pelajar Institusi Pengajian Tinggi Terhadap Simptom Stres Yang Dialami Ketika Sesi Pengajaran Dan Pembelajaran Dalam Talian Era Covid-19". al-Irsyad: Journal of Islamic and Contemporary 6(1): 615-627. https://al-irsyad.kuis.edu.my/index.php/alirsyad/article/view/136.

Desmita, D. (2010). Perkembangan Peserta Didik. Bandung: Remaja Rosda Karya.

Elias, H., Ping, W. S., \& Abdullah, M. C. (2011). Stress and academic achievement among undergraduate students in Universiti Putra Malaysia. Procedia-Social and Behavioral Sciences, $29,646-655$.

Folkman, S. (1984). Personal control and stress and coping processes: a theoretical analysis. Journal of personality and social psychology, 46(4), 839.

Folkman, S., \& Lazarus, R. S. (1980). An analysis of coping in a middle-aged community sample. Journal of health and social behavior, 219-239

Friedlander, L. J., Reid, G. J., Shupak, N., \& Cribbie, R. (2007). Social support, self-esteem, and stress as predictors of adjustment to university among first-year undergraduates. Journal of college student development, 48(3), 259-274.

Gao, J., Zheng, P., Jia, Y., Chen, H., Mao, Y., Chen, S., Wang, Y., Fu, H., Dai, J. (2020). Mental health problems and social media exposure during COVID-19 outbreak. Hashimoto K, ed. PLoS One. ;15(4):e0231924. doi:10.1371/journal.pone.0231924

Hanina, H.H, Tan, P, M. \& Jumali H.S. (2010). Stres dan Pencapaian Akademik Mahasiswa Pembangunan Manusia Di Universiti Putra Malaysia. Jurnal Personalia Pelajar. Bil. $13(57$ 72). Retrieved from http://www.ukm.my/personalia/wp-content/uploads/2015/06/4-HaninaH.pdf.

Higgins J P T, Altman D G, GÃ tzsche P C, JÃ²/4ni P, Moher D, Oxman A D et al. (2011). The Cochrane Collaboration's tool for assessing risk of bias in randomised trials, BMJ; 343 :d5928 doi:10.1136/bmj.d5928

Husky, M, M., Masfety, V, K. \& Swendsen, J, D. (2020). Stress and Anxiety Among University Students In France During Covid-19mandatory Confinement. Elsevier. Retrieved from https://reader.elsevier.com/reader/sd/pii/S0010440X2030033X?token=6DBC1EA24F794E353F D4DC59A501A0B085B02CB2D3C85CECAD3CCA3A4760D7AF78C4D569DD8211EC3174 9DDC3B926E68\&originRegion=eu-west-1\&originCreation=20210930080136

Institute for Public Health. (2019). National Health and Morbidity Survey (NHMS): NonCommunicable Diseases, Healthcare Demand, and Health Literacy-Key Findings. Perpustakaan Negara Malaysia; 2020. Accessed October 31, 2020. http://iptk.moh.gov.my/images/technical_report/2020/4_Infographic_Booklet_NHMS_2019_English.pdf

Ismail, M. N. (2020). Cabaran kepimpinan dalam pengurusan pembelajaran digital. Jurnal Refleksi Kepemimpinan, (JILID III). 
DOI: https://doi.org/10.47405/mjssh.v6i11.1172

Jafar, M. F., Amran, Z. A., Yaakob, M. F. M., Yusof, M. R., \& Awang, H. (2020). Kesediaan pembelajaran dalam talian semasa pandemik Covid-19. In Prosiding Seminar Darulaman (pp. 404-410).

Jamaluddin, N. Mohamad, N. (2020). Pandemik Covid-19: Norma baharu dalam industri pembinaan di Malaysia.https://news.uthm.edu.my/ms/2020/05/pandemikcovid-19-norma-baharu-dalamindustri-pembinaan-di-malaysia/Johar, S. S., \& Amat, M. I. (2020). Krisis Impak Pandemik Covid-19 Dari Dimensi Dan Perspektif Kesihatan Mental Sejagat.

Johari, M. A. (2019). Persepsi tekanan akademik dan kesejahteraan diri di dalam kalangan pelajar universiti di Serdang, Selangor. Educatum Journal of Social Sciences, 5(1), 24-36.

Kamsani, I. I., \& Mahat, A. (2021). Covid 19: Impak E-Pembelajaran Terhadap Kesihatan Pelajar Universiti. Jurnal Dunia Pendidikan, 3(3), 53-60.

Kundu, S. (2020). Present Scenario of 'online Education'During Covid-19 Pandemic. The Management Accountant Journal, 55(11), 94-101.

Lazarus, R. S., Dunkel-Schetter, C., DeLongis, A., \& Gruen, R. J. (1986). Dynamics of a stressful encounter: Cognitive appraisal, coping, and encounter outcomes. Journal of Personality and Social Psychology, 50(5), 992-1003.

Linn, M.C. (1980), Free-choice experiences: How do they help children learn?. Sci. Ed., 64: 237248. https://doi.org/10.1002/sce.3730640213

Matthew, H.E.M., Larson, L.R., Sharaievska, I., Rigolon, A., McAnirlin, O., Mullenbach, L., et al. (2021) Psychological impacts from COVID19 among university students: Risk factors across seven states in the United States. PLoS ONE, 16(1): e0245327

Md Lukmanul Hakim, N. A., Junaidun, N. A., Mohamamd Fadzil, N. S., \& Mohd Ishar, M. I. (2021). Persepsi Pengguna Internet di Malaysia Semasa Pandemik COVID-19. Malaysian Journal of Social Sciences and Humanities (MJSSH), 6(4), 117 - 125. https://doi.org/https://doi.org/10.47405/mjssh.v6i4.745

Mian A, Khan S. (2020). Coronavirus: The spread of misinformation. BMC Med., 18(1):89. doi:10.1186/s12916-020-01556-3

Misra, R., \& McKean, M. (2000). College students' academic stress and its relation to their anxiety, time management, and leisure satisfaction. American Journal of Health Studies, 16(1), 41-51.

Nawii, A., \& Hamidaton, U. (Eds.). (2020). Penerimaan Pelajar Universiti Sains Islam Malaysia (USIM) Terhadap Penggunaan Microsoft Teams Sebagai Platform Pembelajaran-Satu Tinjauan. Seminar Antarabangsa Islam Dan Sains (SAIS 2020). https://oarep.usim.edu.my/jspui/handle/123456789/6838

Nor Sahara, M \& Zulkarnain, A, M. (2021). Kajian Kesediaan Pelajar Mengikuti Pembelajaran Dalam Talian Semasa Perintah Kawalan Pergerakan (Pkp) Membendung Covid-19 Fasa 2. International Journal of Education and Pedagogy, 3(1), 195-202. Retrieved from https://myjms.mohe.gov.my/index.php/ijeap/article/view/12999/6718.

Norhana, A., Fahmi, A., Aslinda, M. \& Zazalli, L. (2020). Analisis Faktor Tekanan Yang Mempengaruhi Pelajar Kolej Komuniti Negeri Johor Ketika Perintah Kawalan Pergerakan. Jurnal Dunia Pendidikan, 2(3), 158-172. Retrived from https://myjms.mohe.gov.my/index.php/jdpd/article/view/11157.

Nwachukwu I, Nkire N, Shalaby R, Marianne Hrabok, M., Vuong, W., Gusnowski, A., Surood, S., Urichuk, L., Greenshaw, A. J. \& Agyapong, V. I. O. (2020). Covid-19 pandemic: Age-related differences in measures of stress, anxiety and depression in Canada. Int $J$ Environ Res Public Health., 17(17):1-10. doi:10.3390/ijerph17176366

Pan, K.Y., Kok, A. A. L., Eikelenboom, M., Horsfall, E., Jörg, F., Luteijn, R. A., Rhebergen, D., Oppen, P. V., Giltay, E. J. \& Penninx, P. J. H. (2020). The mental health impact of the COVID19 pandemic on people with and without depressive, anxiety, or obsessive-compulsive disorders: a longitudinal study of three Dutch case-control cohorts. The Lancet Psychiatry. doi:10.1016/S2215-0366(20)30491-0

Pascoe, M. C., Hetrick, S. E., \& Parker, A. G. (2020). The impact of stress on students in secondary school and higher education. International Journal of Adolescence and Youth, 25(1), 104-112.

Pfefferbaum, B., North, C.S. (2020). Mental Health and the Covid-19 Pandemic. N Engl J Med, 383(6), 510-512. doi:10.1056/nejmp2008017 
Puwaneswarry M, Ayeshah ZN, Gaaitheri K, Lim, K. Q., Wong, Y. H., Tang, S. L. \& Ng, C. G. (2020). Development of Knowledge, Attitudes, and Practices (KAP) Towards COVID-19 Pandemic in Malaysia, 15(2):262-275. doi:10.17576/MH.2020.1502.23

Rogowska, A. M., Kuśnierz, C., \& Bokszczanin, A. (2020). Examining anxiety, life satisfaction, general health, stress and coping styles during COVID-19 pandemic in Polish sample of university students. Psychology Research and Behavior Management, 13, 797.

Rosdi, A. Z., Hassan, S. N. S., \& Mahfuz, M. S. (2021). Penerimaan Pelajar dan Penggunaan MPembelajaran Terhadap Pengajian Hadis: Student Acceptance and Use of M-Learning toward Hadith Studies. Journal of Quran Sunnah Education \& Special Needs, 5(1), 100-112.

Saad, S. S., Wan Zaimah, D., Zahrul, A., \& Hussain, O., Harliana, H., Khairul, A, (2018). Pengurusan Stres Dalam Kalangan Pelajar Universiti. Research Gate. Retrieved from https://www.researchgate.net/publication/322222527_PENGURUSAN_STRES_DALAM_KA LANGAN_PELAJAR_UNIVERSITI

Salleh, M., Jamaludin, M. F., Safie, N. S. M., \& Yusof, J. M. (2021). Tinjauan Keberkesanan Pembelajaran Secara dalam Talian Ketika Pandemik Covid-19: Perspektif Pelajar Sains Kejuruteraan Politeknik Ibrahim Sultan. Jurnal Dunia Pendidikan, 3(1), 374-384

Selian, S. N., Hutagalung, F. D., \& Rosli, N. A. (2020). Pengaruh stres akademik, daya tindak dan adaptasi sosial budaya terhadap kesejahteraan psikologi pelajar universiti. JuPiDi: Jurnal Kepimpinan Pendidikan, 7(2), 36-57.

Shaher. H.H, Hanan. A, Mu'ath. T. (2021). Derpession, anxiety and stress among undergraduate students during Covid 19 aoutbreak and home quarantine. Nursing Open, 00:1-9

Simon J, Helter TM, White RG, Van Der Boor C, Łaszewska A. Impacts of the Covid-19 lockdown and relevant vulnerabilities on capability well-being, mental health and social support: an Austrian survey study. BMC Public Health, 2l(1). doi:10.1186/s12889-021-10351-5

Sinha, B.K., Willson, L.R., and Watson, D.C. (2000). Stress and coping among students in India and Canada. Canadian Journal of Behavioural Science, 32(4).

Sood, S. 2020. Psychological Effects of the Coronavirus Disease-2019 Pandemic. RHiME7. 23-26.

Sundarasen, S., Chinna, K., Kamaludin, K., Nurunnabi, M., Baloch, G. M., Khoshaim, H. B., Abid Hossain, S. F. \& Sukayt, A. (2020). Psychological Impact of COVID-19 and Lockdown among University Students in Malaysia: Implications and Policy Recommendations. Int. J. Environ. Res. Public Health, 17, 6206; doi:10.3390/ijerph17176206

Talha,R. (2020). Kajian kes impak perintah kawalan pergerakan kepada penduduk Malays ia. Department of Statistics Malaysia Official Portal. https://www.dosm.gov.my/v1/uploads/files/6_Newsletter/Newsletter\%202020/DOS M_BPPD_12020_Siri17.pdf

Tasir \& Zaidatun (2006) Learning "goal programmning" using an interactive multimedia courseware : design factors and students' preferences. Malaysain Online Journal of Instructional Technology (MOJIT), 3(1), 85-95.

Tasir, Z., Harun, J., \& YEN, L. S. (2006). Faktor Penggunaan Komputer Dan Kaitannya Dengan Kesediaan Mengikuti Pembelajaran Dalam Talian Di Kalangan Pelajar Sarjana. Sains Humanika, 44(1).

Wong, K., Kwan, R., Wang, F. L., \& Luk, L. (2013, August). Students' experience and perception on e-learning using social networking. In International Conference on Hybrid Learning and Continuing Education (pp. 269-279). Springer, Berlin, Heidelberg.

Woon, L. S.-C., Abdullah, M. F., Sidi, H., Mansor, N. S., \& Jaafar, N. R. (2021). Depression, anxiety, and the COVID-19 pandemic: Severity of symptoms and associated factors among university students after the end of the movement lockdown, DOI:10.1371/journal.pone.0252481.

World Health Organisation. ( 2020, October 31). Coronavirus Disease (COVID-19). Accessed October 31, 2020. https://www.who.int/emergencies/diseases/novel-coronavirus-2019

World Health Organization. (2020). Coronavirus disease (COVID-19) advice for the public: Mythbusters. Accessed December 28, 2020. https://www.who.int/emergencies/diseases/novelcoronavirus-2019/advice-for-public/myth-busters $\# 5 \mathrm{~g}$

World Health Organization. (2020, March 11). WHO Director-General's opening remarks at the media $\begin{array}{lllll}\text { briefing on COVID-19. Accessed } 2020 . & \text { September }\end{array}$ https://www.who.int/dg/speeches/detail/who-director-general-s-opening-remarks-at-the-mediabriefing-on-covid-19---11-march-2020 
Xiao, H., Zhang, Y., Kong, D., Li, S., \& Yang, N. (2019). The effects of social support on sleep quality of medical staff treating patients with coronavirus disease 2019(COVID-19) in January and February 2020 in China. PubMed. DOI: 10.12659/MSM.923549

Xiao, Y., \& Watson, M. (2019). Guidance on Conducting a Systematic Literature Review. Planning Research. Journal of Planning Education and Research, 39 (1), 93-112. https://10.1177/0739456X17723971

Yahaya, M., Azman, A., Mohamad Yusof, M., Kamarul Bahrin, F., \& Md Akhir, N. (2020). Halangan masyarakat dalam sistem penyampaian program pendidikan: satu kajian kes di baling, Kedah. KHIDMAT SOSIAL, Journal of Social Work and Social Service, 1(2), 60-75

Yahaya, Mahathir and Hayat Adnan, Wardatul (2021). Cabaran pelajar melalui kaedah pembelajaran atas talian: kajian institusi pengajian tinggi awam Malaysia / Mahathir Yahaya and Wardatul Hayat Adnan. Journal of Media and Information Warfare (JMIW), 14, 11-20.

Yasmin, H., Khalil, S., \& Mazhar, R. (2020). COVID 19: Stress Management Among Students and Its Impact on Their Effective Learning. International Technology and Education Journal, 4(2), 6574. Retreived from https://files.eric.ed.gov/fulltext/EJ1286695.pdf.

Zainora, D., Noorhafizah, M, H., Norazman, A \& Anuar, H. (2021). Kajian Perbandingan Kalangan Pelajar Institusi Pengajian Tinggi Terhadap Simptom Stres Yang Dialami Ketika Sesi Pengajaran Dan Pembelajaran Dalam Talian Era Covid-19. Journal Al Irsyad, 6(1). Retrieved from https://al-irsyad.kuis.edu.my/index.php/alirsyad/article/view/136/90.

Zhou, J., Liu, L., Xue, P., Yang, X., \& Tang, X. (2020). Mental Health Response to the COVID-19 Outbreak in China. Am J Psychiatry, 177(7), 574-575. doi:10.1176/appi.ajp.2020.20030304 doi:10.12659/MSM.923549

Zulkifli, N. A., Chong, N., Guan, Z., Zuraida, N., \& Tang Song, L. (2021). Psychosocial Factors Associated with Depression and Anxiety During COVID-19 Pandemic Among Outpatients with Depression. Alpha Psychiatry, 185-193.

Zulkifli, N. A., Sivapatham, S., \& Guan, N. C. (2020). Brief psychotic disorder in relation to coronavirus, COVID-19 outbreaks: a case report. Malaysian Journal of Psychiatry, 29(1), 6772. 